\title{
Galanin inhibits glucagon-like peptide-1 secretion through pertussis toxin-sensitive $G$ protein and ATP-dependent potassium channels in rat ileal L-cells
}

\author{
S Saïfia ${ }^{1}$, A-M Chevrier ${ }^{1}$, A Bosshard ${ }^{1}$, J-C Cuber ${ }^{1,2}$, \\ J-A Chayvialle ${ }^{1}$ and J Abello ${ }^{1}$ \\ ${ }^{1}$ Unité INSERM 45, Hôpital Edouard Herriot, 69437 Lyon Cedex 3, France and ${ }^{2}$ Unité d'Ecologie et de Physiologie du Système Digestif, INRA, \\ 78352 Jouy-en-Josas, France \\ (Requests for offprints should be addressed to J Abello, INSERM Unité 45, Hôpital Edouard Herriot, Pavillon Hbis, Place d’Arsonval, 69437 Lyon Cedex 3 , \\ France)
}

\begin{abstract}
The neuropeptide galanin is widely distributed in the gastrointestinal tract and exerts several inhibitory effects, especially on intestinal motility and on insulin release from pancreatic $\beta$-cells. The presence of galanin fibres not only in the myenteric and submucosal plexus but also in the mucosa, prompted us to investigate the regulatory role of galanin, and its mechanism of action, on the secretion of the insulinotropic hormone glucagon-like peptide-1 (GLP-1). Rat ileal cells were dispersed through mechanical vibration followed by moderate exposure to hyaluronidase, DNase I and EDTA, and enriched for L-cells by counterflow elutriation. A 6- to 7-fold enrichment in GLP-1 cell content was registered after elutriation, as compared with the crude cell preparation $(929 \pm 81$ vs $138 \pm 14 \mathrm{fmol} / 10^{6}$ cells). L-cells then accounted for $4-5 \%$ of the total cell population. Bombesin induced a time(15-240 min) and dose- $(0 \cdot 1 \mathrm{nM}-1 \mu \mathrm{M})$ dependent release of GLP-1. Glucose-dependent insulinotropic
\end{abstract}

peptide (GIP, $100 \mathrm{nM})$, forskolin $(10 \mu \mathrm{M})$ and the phorbol ester 12-0-tetradecanoylphorbol-13-acetate (TPA, $1 \mu \mathrm{M}$ ) each stimulated GLP-1 secretion over a 1-h incubation period. Galanin (0.01-100 nM) induced a dose-dependent inhibition of bombesin- and of GIP-stimulated GLP-1 release (mean inhibition of $90 \%$ with $100 \mathrm{nM}$ galanin). Galanin also dose-dependently inhibited forskolininduced GLP-1 secretion (74\% of inhibition with $100 \mathrm{nM}$ galanin), but not TPA-stimulated hormone release. Pretreatment of cells with $200 \mathrm{ng} / \mathrm{ml}$ pertussis toxin for $3 \mathrm{~h}$, or incubation with the ATP-sensitive $\mathrm{K}^{+}$channel blocker disopyramide $(200 \mu \mathrm{M})$, prevented the inhibition by galanin of bombesin- and GIP-stimulated GLP-1 secretion. These studies indicate that intestinal secretion of GLP-1 is negatively controlled by galanin, that acts through receptors coupled to pertussis toxin-sensitive $G$ protein and involves ATP-dependent $\mathrm{K}^{+}$channels.

Journal of Endocrinology (1998) 157, 33-41

\section{Introduction}

Endocrine intestinal L-cells, mainly located in the distal small intestine and in the colon, synthesize proglucagonderived peptides including glicentin, oxyntomodulin, glucagon-like peptide-1(7-36) $\mathrm{NH}_{2}$ (GLP-1) and GLP-2. Glicentin and oxyntomodulin both constitute the so-called enteroglucagon-like immunoreactivity (GLI). GLP-1 is the most potent known incretin, stimulating glucosedependent insulin secretion in vivo and in a variety of experimental systems (for reviews, see Holst 1994, Thorens 1995). Furthermore, GLP-1 has been shown to suppress glucagon release from the pancreas, to inhibit gastric secretion, to enhance the sensitivity of pancreatic $\mathrm{B}$-cells to glucose and to participate in the central regulation of feeding. Due to its glucose-dependent insulino- tropic effects, GLP-1 has been proposed as a potential therapeutic agent in the treatment of Type II diabetes (Gutniak et al. 1994, 1996).

Various experimental approaches have been used to examine the regulation of intestinal L-cells. On the one hand, several luminal factors including glucose, bile salts and dietary fibres are potent stimulants of GLP-1 secretion (Roberge \& Brubaker 1991, Reimer \& McBurney 1996). On the other hand, several regulatory peptides including glucose-dependent insulinotropic peptide (GIP), peptides of the bombesin/gastrin-releasing peptide (GRP) family, calcitonin-gene related peptide (CGRP), as well as cholinergic agonists were shown to elicit GLP-1 secretion in vivo and ex vivo in a model of isolated vascularly perfused intestinal loops (Plaisancié et al. 1994, Dumoulin et al. 1995, Herrmann-Rinke et al. 1995). The establishment of 
in vitro models, based on the use of short-term cultures of dispersed foetal rat intestinal cells or of rat dispersed intestinal cells enriched in L-cells, led to results supporting these observations (Brubaker 1988, Brubaker \& Vranic 1987, Saifia et al. 1994, Huang \& Brubaker 1995).

Apart from the reported action of somatostatin on GLI peptide secretion (Sagor et al. 1985, Brubaker 1991), little is known about the intestinal inhibitory influences that reduce the postprandial discharge of GLP-1. Galanin, a 29 -amino acid neuropeptide originally isolated from porcine small intestine, is widely distributed in the gastrointestinal tract. Galanin-like immunoreactivity is found in nerve cell bodies and fibres of the myenteric plexus and submucosal plexus (Rattan 1991). Galanin participates in the regulation of intestinal motility and inhibits pancreatic exocrine secretion and insulin release from B-cells (Crawley 1995). It was also shown, in vivo and ex vivo with the isolated vascularly perfused rat ileal model, that galanin reduced the secretory activity of L-cells (Bauer et al. 1989, Herrmann-Rinke et al. 1996). Since intestinal endocrine cells are under the influence of mediators released from the enteric nervous system, a model of endocrine cells, uncoupled from the underlying lamina propria, is required for further identification of signal transduction pathways put into play by regulatory factors that directly modulate hormone release.

For this purpose, we developed an in vitro model of rat dispersed ileal cells enriched in L-cells by counterflow elutriation, to examine the effect of galanin on the secretion of GLP-1. We here report that galanin potently inhibits forskolin-, bombesin- and GIPstimulated GLP-1 secretion. These effects involve a pertussis toxin-sensitive $\mathrm{G}$ protein and ATP-dependent $\mathrm{K}^{+}$channels.

\section{Materials and Methods}

\section{Materials}

The following solutions were used: Hank's balanced salt solution (HBSS, Sigma Chemical Co., Saint Quentin Fallavier, France) supplemented with $\mathrm{NaHCO}_{3} 4 \mathrm{mM}$, Hepes $10 \mathrm{mM}$, streptomycin sulphate $(1 \mathrm{~g} / \mathrm{l})$, penicillin $\mathrm{G}$ $(160000 \mathrm{IU} / \mathrm{l})$ and $0 \cdot 1 \%$ bovine serum albumin (BSA), pH 7.4; basal medium Eagle (BME, Life Technologies, Cergy Pontoise, France) supplemented with $\mathrm{NaHCO}_{3}$ $26 \mathrm{mM}$, Hepes $10 \mathrm{mM}$, glutamine $2 \mathrm{mM}$, BSA $0 \cdot 1 \%$ and containing $100 \mathrm{mg} / \mathrm{l}$ hyaluronidase and $10 \mathrm{mg} / 1$ DNase I (Boehringer, Mannheim, Germany). The $\mathrm{pH}$ was adjusted to 7•4; Earle's balanced salt solution (EBSS, Life Technologies) supplemented with $\mathrm{NaHCO}_{3} 26 \mathrm{mM}$, Hepes $10 \mathrm{mM}$, glutamine $2 \mathrm{mM}$, BSA $0 \cdot 1 \%$ and ethylene diaminetetraacetic acid (EDTA) $1 \mathrm{mM}, \mathrm{pH} 7 \cdot 4$; HAM/ F-12 medium (Life Technologies) supplemented with $\mathrm{NaHCO}_{3} 12 \mathrm{mM}$, Hepes $20 \mathrm{mM}$, glutamine $2 \mathrm{mM}$ and BSA $0 \cdot 1 \%, \mathrm{pH} 7 \cdot 4$.
Bombesin, GIP, rat galanin, GLP-1(1-36)amide, GLP1(7-36)amide, GLP-1(1-37), GLP-1(7-37), forskolin, 12-0-tetradecanoylphorbol-13-acetate (TPA), 4- $\alpha$ phorbol, pertussis toxin and disopyramide were obtained from Sigma. Fluorescein isothiocyanate-conjugated anti-rabbit immunoglobulin G was obtained from Nordic (Tilburg, The Netherlands). All other reagents were of analytical grade.

\section{Cell isolation}

Male Wistar rats (200-250 g) were killed by cervical dislocation and the abdomens were quickly opened. The distal part of the small intestine, about $30 \mathrm{~cm}$ long, was removed, washed first in saline at $4{ }^{\circ} \mathrm{C}$ then in HBSS (without BSA), and incubated at $37^{\circ} \mathrm{C}$ for 15 min under a continuous 95\% $\mathrm{O}_{2}-5 \% \mathrm{CO}_{2}$ flow. After this equilibrium period, the ileum was everted on a glass spiral (diameter $3 \mathrm{~mm}$ ) and connected to a vibro-mixer (Vibro Mischer, Chemap, Switzerland). The intestinal segment was immersed in $120 \mathrm{ml}$ HBSS buffer and vertically vibrated for $5 \mathrm{~min}$ (60 vibrations/s, $2 \mathrm{~mm}$ amplitude). The resulting cell medium, containing mainly villous cells and mucus, was discarded, and the ileum was again vibrated for $15 \mathrm{~min}$ at 120 vibrations/s (amplitude $2 \mathrm{~mm}$ ). The cell suspension (aggregates of 5-15 cells) was centrifuged $\left(100 \mathrm{~g}\right.$ for $5 \mathrm{~min}$ at $20^{\circ} \mathrm{C}$ ) and incubated in a shaker for 5 min at $20^{\circ} \mathrm{C}$ with EBSS. After washing, the cells were again incubated for $5 \mathrm{~min}$ at $20^{\circ} \mathrm{C}$ in BME containing $100 \mathrm{mg} / \mathrm{l}$ hyaluronidase and $10 \mathrm{mg} / \mathrm{l}$ DNase I. After two washing steps in HBSS and filtration through 250 and $75 \mu \mathrm{m}$ nylon meshes, the final cell suspension mainly consisted of single cells. Cell number was estimated with a haematometer and cell viability was assessed by $0 \cdot 05 \%$ trypan blue exclusion.

\section{Cell fractionation}

Dispersed ileal cells were separated by counterflow elutriation according to their sedimentation velocities with a Beckman elutriator rotor (model JE-5.0, Beckman Instruments, Los Angeles, CA, USA) run in a centrifuge (model J-6M/E, Beckman). A peristaltic pump (Masterflex, Chicago, IL, USA) was used to load the cell suspension $\left(200 \times 10^{6}\right.$ cells/elutriation) into the separation chamber. Five different cell fractions $(100 \mathrm{ml}$ each) were collected at the following combinations of flow rate $(\mathrm{ml} / \mathrm{min})$ and rotor velocities (revolutions/min): 1:25 and 2500; 2:30 and 2200; 3:45 and 2200; 4:55 and 2000; 5:100 and 2000. Elutriated fractions were centrifuged $(100 \boldsymbol{g}$ for $5 \mathrm{~min}$ at $20^{\circ} \mathrm{C}$ ) and the cell pellets were homogenized in $1 \mathrm{ml}$ extraction medium ( $2 \mathrm{M}$ acetic acid $+20 \mathrm{mM} \mathrm{HCl})$ at $4{ }^{\circ} \mathrm{C}$ and then sonicated. The homogenate was placed in a heating block for $10 \mathrm{~min}$ at $100{ }^{\circ} \mathrm{C}$, neutralized with $2.5 \mathrm{M} \mathrm{NH} \mathrm{N}_{4} \mathrm{OH}$ and stored at $-20{ }^{\circ} \mathrm{C}$ until radioimmunoassay (RIA). The elutriated fractions containing 
maximum GLP-1 concentrations were pooled, centrifuged $\left(100 \mathrm{~g}\right.$ for $5 \mathrm{~min}$ at $\left.20^{\circ} \mathrm{C}\right)$, resuspended in complete HAM/F12 at a concentration of $10^{6} \mathrm{cells} / \mathrm{ml}$ and immediately used for release studies.

\section{Peptide release}

Test tubes containing $0.9 \times 10^{6}$ native cells were incubated at $37{ }^{\circ} \mathrm{C}$ under a continuous $95 \% \mathrm{O}_{2}-5 \% \mathrm{CO}_{2}$ flow in an orbital shaker for the indicated time, with or without the tested agents. The cell suspensions were then centrifuged and the supernatants were immediately frozen at $-20{ }^{\circ} \mathrm{C}$ for RIA. Cell pellets from both unstimulated and stimulated conditions were treated as described above for GLP-1 determination.

\section{Peptide assays}

GLP-1 concentrations were measured by RIA as previously described (Abello et al. 1994, Saifia et al. 1994). Gel filtration on a $5 \times 100 \mathrm{~cm}$ Sephadex G-50 column revealed in elutriated cells and in the release medium the presence of a single peak corresponding to the position of synthetic GLP-1(7-36)amide and GLP-1(1-36)amide, which were indistinguishable in the present system. Peptide YY (PYY), somatostatin and neurotensin were measured as previously described (Chayvialle et al. 1978, Cuber et al. 1990, Dumoulin et al. 1995).

\section{Histological analysis}

Freshly removed, full-thickness, ileal wall samples were immersed in an ice-cold PBS solution containing 0.4\% $p$-benzoquinone for $2 \mathrm{~h}$ at $4{ }^{\circ} \mathrm{C}$. They were repeatedly rinsed in PBS containing $10 \%$ sucrose at $4{ }^{\circ} \mathrm{C}$ and frozen in liquid nitrogen. Adjacent sections were sliced with a Bright cryostat. Galanin and GLP-1 immunoreactivities were detected with the indirect immunofluorescence technique of Coons et al. (1955). Antiserum 51162C raised in rabbit against synthetic porcine galanin (Philippe et al. 1990) and antiserum 199D were diluted (1:100) in PBS containing 3\% Triton X-100 and 5\% BSA ( $\mathrm{pH} 7 \cdot 4)$ for $1 \mathrm{~h}$ in a humid chamber at room temperature. After three washing steps with PBS, sections were incubated for $1 \mathrm{~h}$ at room temperature with fluorescein isothiocyanateconjugated antirabbit immunoglobulin G diluted 1:100 in PBS. After washing, sections were mounted in a nonaqueous medium (Fluoprep, Biomérieux, Marcy l'Etoile, France) and examined with a Leitz fluorescence microscope. To test the specificity of the immunostaining, sections were incubated with antisera $51162 \mathrm{C}$ or 199D that had been preadsorbed with galanin and GLP-1 $(1 \mu \mathrm{mol} / \mathrm{ml}$ undiluted antiserum) respectively.

Microscopic slides of cell suspensions $\left(1 \times 10^{5}\right.$ cells $)$ obtained after elutriation were prepared using a cytocentrifuge (Shandon Southern Instruments, Sewickley,
PA, USA). Slides were fixed in acetone for $10 \mathrm{~min}$ at $4{ }^{\circ} \mathrm{C}$ and washed three times with PBS, pH 7·4. GLP-1 immunoreactivity-containing cells were visualized by indirect immunofluorescence using the antiserum 199D. For control purposes, cells were incubated with GLP-1 antiserum preabsorbed with GLP-1 $(1 \mu \mathrm{mol} / \mathrm{ml}$ undiluted antiserum). Cells were also visualized by alkaline phosphatase stain with the fast red stain Cadenzatags kit (Shandon Southern Instruments).

\section{Data analysis}

Peptide release (mean \pm S.E.M.) was expressed for control and treated cells as fmol/ $10^{6}$ cells. Statistical analysis was performed by analysis of variance (ANOVA), followed by Student's $t$-test for comparisons of means. Differences were considered significant at $P<0 \cdot 05$.

\section{Results}

Immunofluorescence of galanin nerve fibres in ileal mucosa

Galanin immunoreactive fibres could be identified using the antiserum 51162C in the rat ileal mucosa (Fig. 1a). Similarly after incubation with the antiserum 199D, several GLP-1 immunoreactive cells were revealed in an adjacent ileal villous (Fig. 1b). No labelling was detected after incubation of antisera with homologous antigens. The distribution of galanin immunoreactive nerves in the ileum, in close apposition with the L-cells, thus suggests a possible regulatory function of the neuropeptide on the secretion of GLP-1.

\section{Isolation of GLP-1-enriched cells}

After combination of mechanical and enzymatic dispersion, the resulting cell number was $314 \cdot 8 \pm 27 \cdot 410^{6}$ cells (mean of 31 preparations, each preparation including two rats). GLP-1 concentration was $138 \pm 14 \mathrm{fmol} / 10^{6}$ cells $(n=20)$. Cell viability, determined by trypan blue exclusion, always exceeded $90 \%$. Figure 2 shows the concentration of GLP-1 and the cell number in the different fractions obtained after counterflow elutriation. Fractions 3 and 4 contained the maximum amount of GLP-1 and were pooled for release studies. GLP-1 concentration in the enriched cell suspension was $929 \pm 81 \mathrm{fmol} / 10^{6}$ cells, with a 6- to 7-fold enrichment over the crude suspension. Cell content in PYY was also significantly enriched (944 \pm 99 vs $155 \pm 21 \mathrm{fmol} / 10^{6}$ cells, $\left.P<0 \cdot 05\right)$. The mean apparent diameter of the GLP-1-enriched cells, as calculated from the rates of centrifugation and elutriation according to Stoke's law, was 13-19 $\mu \mathrm{m}$. Upon counting the cells labelled at immunofluorescence (Fig. 3) or alkaline phosphatase staining, the elutriated preparation contained $4-5 \%$ of L-cells, when they represented 

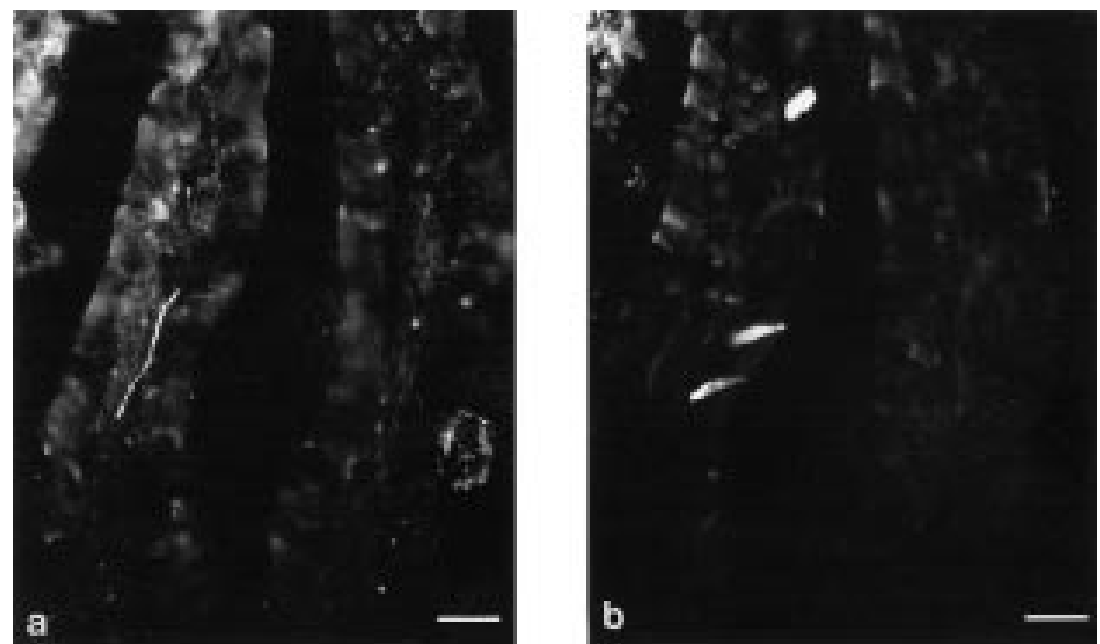

Figure 1 Immunofluorescence micrographs of two adjacent sections of the ileum villous in the rat after incubation with galanin antiserum 51162C (a) and GLP-1 antiserum 199D (b). (a) A galanin-like immunoreactive fibre can be observed in the villous. (b) The adjacent section shows two GLP-1 immunoreactive cells. Scale bars $=25 \mu \mathrm{m}$.

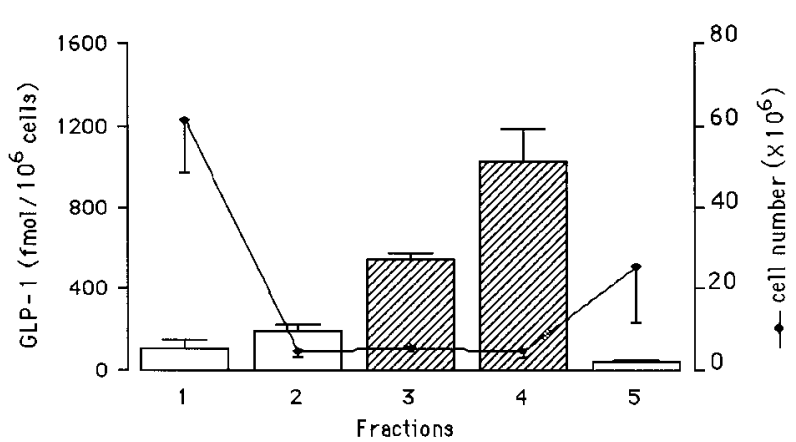

Figure 2 Concentration of GLP- 1 (in fmol $/ 10^{6}$ cells, bars, left scale) and cell number (points, right scale) in the serial fractions obtained from the elutriator after cell dispersion. Fractions 3 and 4 were kept and pooled for studies on release (means \pm S.E.M. of four separate experiments).

less than $1 \%$ in the initial cell suspension. Crude cell preparation also contained immunoreactive neurotensin $\left(343 \pm 48 \mathrm{fmol} / 10^{6}\right.$ cells $)$ and somatostatin $(20 \pm 3 \mathrm{fmol} /$ $10^{6}$ cells), that were significantly increased after elutriation $\left(3017 \pm 253\right.$ and $78 \pm 26 \mathrm{fmol} / 10^{6}$ cells respectively, $P<0 \cdot 05)$. Vasoactive intestinal polypeptide, substance $\mathrm{P}$ and galanin were undetectable as judged by RIA and by immunofluorescence.

\section{Agonist-dependent release of GLP-1}

The responsiveness of the enriched L-cell preparation was assessed with bombesin, which is a potent stimulant of GLP-1 secretion (Fig. 4). Bombesin $\left(10^{-6} \mathrm{M}\right)$ produced a time-dependent release of GLP-1 (Fig. 4, left panel), significant from $30 \mathrm{~min}$ on $(65 \cdot 6 \pm 4 \cdot 3 \mathrm{vs} 40 \cdot 2 \pm 5 \cdot 1 \mathrm{fmol} /$
$10^{6}$ cells, $\left.P<0 \cdot 05\right)$. The secretion increased up to $4 \mathrm{~h}$, representing $210 \cdot 2 \pm 16 \cdot 2 \mathrm{fmol} / 10^{6}$ cells. Bombesin induced over a $1-\mathrm{h}$ incubation period a dose-dependent $\left(10^{-10}-10^{-6} \mathrm{M}\right)$ release of GLP-1 (Fig. 4, right panel), which was first significant at $10^{-8} \mathrm{M}$ and maximal at $10^{-6} \mathrm{M}\left(73 \cdot 7 \pm 4 \cdot 9 \mathrm{fmol} / 10^{6}\right.$ cells, $\left.P<0 \cdot 05\right)$. Similarly, the insulinotropic peptide GIP, at the pharmacological concentration of $10^{-7} \mathrm{M}$, and forskolin $\left(10^{-5} \mathrm{M}\right)$, that directly stimulates adenylate cyclase, significantly $(P<0 \cdot 05)$ increased the release of GLP-1 (Table 1). A similar rise of GLP-1 secretion was also evidenced in the presence of $10^{-6} \mathrm{M}$ TPA (Table 1). The inactive phorbol ester $4-\alpha$ phorbol $(1 \mu \mathrm{M})$ and the carrier solvent DMSO did not alter basal GLP-1 release (data not shown). Interestingly, none of the tested agonists affected the cellular integrity after incubation at $37^{\circ} \mathrm{C}$ for $1 \mathrm{~h}$, as judged from trypan blue exclusion and release of lactate dehydrogenase (data not shown), suggesting that the increase in GLP-1 found in the medium was due to an enhanced secretion rather than to leakage from damaged cells.

\section{Galanin inhibition of GLP-1 release}

The effects of galanin were investigated on basal and stimulated GLP-1 secretion (Table 1). Galanin alone had no significant effect on the amount of GLP-1 present in the cells nor on GLP-1 release over the concentrations $\left(10^{-11}-10^{-7} \mathrm{M}\right)$ tested (Table 1 and data not shown). In contrast, it dose-dependently inhibited bombesin-induced GLP-1 secretion. The inhibition of GLP-1 release stimulated by $10^{-6} \mathrm{M}$ bombesin was significant at $10^{-9} \mathrm{M}$ galanin and maximal at $10^{-7} \mathrm{M}$, decreasing 


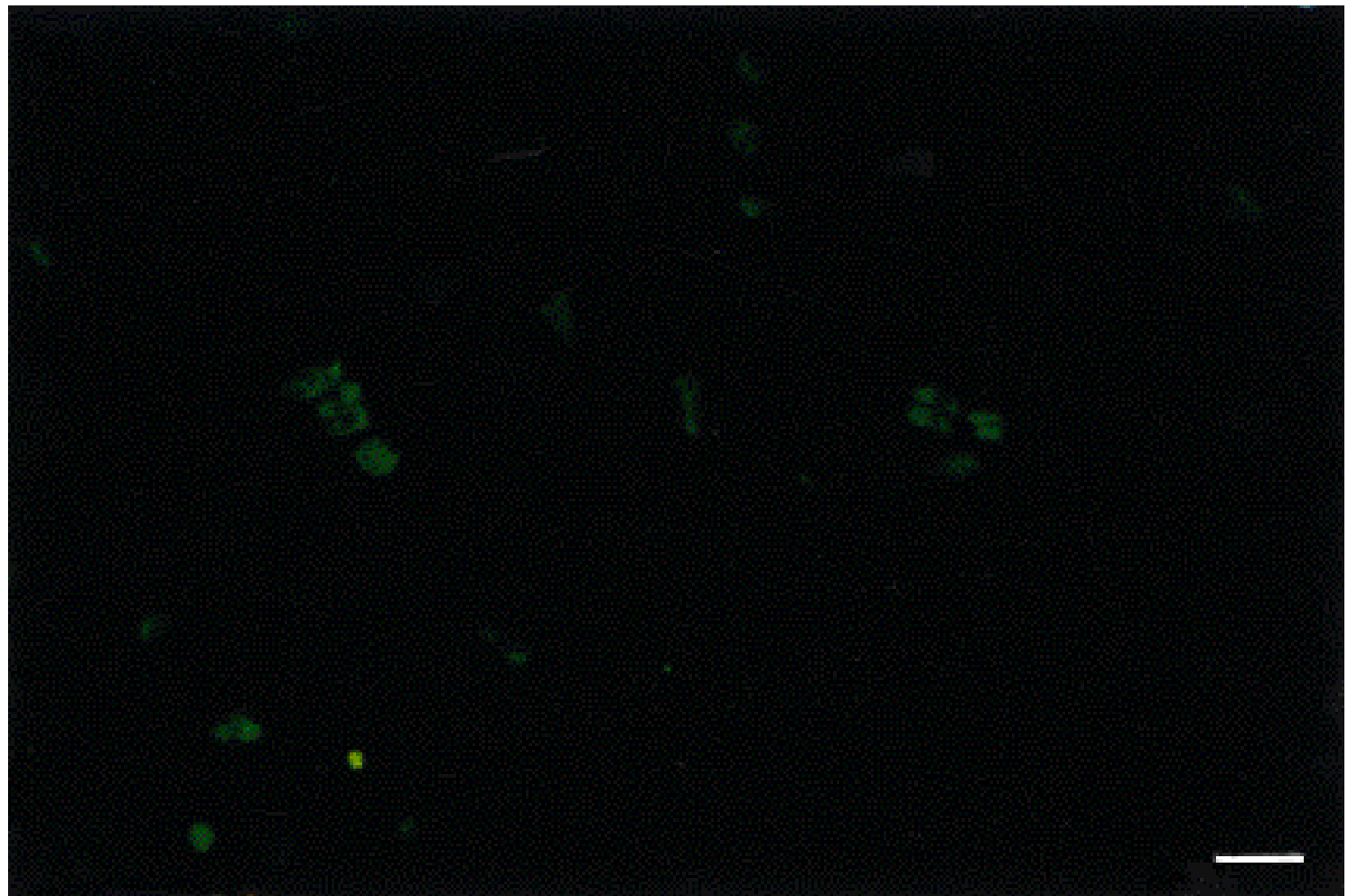

Figure 3 Immunocytochemical localization of GLP-1 in the cells after elutriation (magnification: $\times 280$; scale bar $=25 \mu \mathrm{m}$ ).
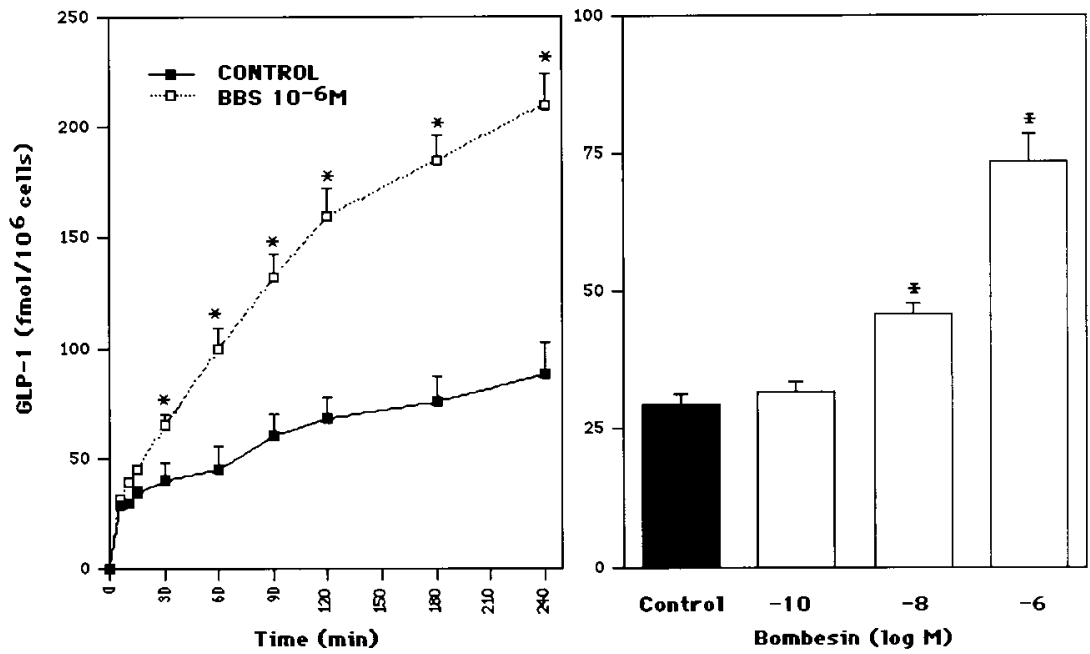

Figure 4 Time- and dose-dependent effect of bombesin (BBS) on GLP-1 release. Left, cells were incubated at $37^{\circ} \mathrm{C}$ for serial times without (closed squares) or with (open squares) $10^{-6} \mathrm{M} \mathrm{BBS}$. Right, cells were incubated at $37^{\circ} \mathrm{C}$ for $1 \mathrm{~h}$ with or without the indicated concentrations of BBS. Results are expressed as fmol $/ 10^{6}$ cells. Data are the means of three separate experiments each performed in triplicate. ${ }^{*}$ Significantly different from control values $(P<0 \cdot 05)$.

GLP-1 secretion to a value close to basal $(P<0 \cdot 05)$. Galanin also inhibited in a dose-dependent fashion $\left(10^{-11}-10^{-7} \mathrm{M}\right)$ GIP-stimulated GLP-1 release. Inhibition of $10^{-7} \mathrm{M}$ GIP-stimulated GLP-1 secretion was significant $(P<0 \cdot 05)$ at $10^{-9} \mathrm{M}$ galanin, and was maximal at $10^{-7} \mathrm{M}$. The effects on the secretion of GLP-1 induced by direct activators of cAMP production or protein kinase $\mathrm{C}$ are shown in Table 1. Addition of galanin 
Table 1 Effect of galanin on GLP-1 secretion (in fmol/10 $10^{6}$ cells) when stimulated by various agonists. Cells were incubated at $37^{\circ} \mathrm{C}$ for $1 \mathrm{~h}$ without or with $10^{-6} \mathrm{M}$ bombesin, $10^{-7} \mathrm{M}$ GIP, $10^{-5} \mathrm{M}$ forskolin or $10^{-6} \mathrm{M}$ TPA, in the absence or presence of increasing concentrations of galanin. Results are expressed as fmol/ $10^{6}$ cells. Data are means \pm S.E.M. of three separate experiments each performed in triplicate

\begin{tabular}{|c|c|c|c|c|}
\hline & \multicolumn{4}{|l|}{ Galanin $(M)$} \\
\hline & 0 & $10^{-11}$ & $10^{-9}$ & $10^{-7}$ \\
\hline \multicolumn{5}{|l|}{ Treatment } \\
\hline No agonist & $31 \cdot 3 \pm 2 \cdot 1$ & $38 \cdot 7 \pm 1 \cdot 3$ & $37 \cdot 4 \pm 2 \cdot 4$ & $36 \cdot 8 \pm 2 \cdot 6$ \\
\hline Bombesin $\left(10^{-6} \mathrm{M}\right)$ & $61 \cdot 1 \pm 4 \cdot 9^{*}$ & $51 \cdot 4 \pm 2 \cdot 4$ & $43 \cdot 1 \pm 2 \cdot 1 \dagger$ & $31 \cdot 7 \pm 2 \cdot 5 \dagger$ \\
\hline $\operatorname{GIP}\left(10^{-7} \mathrm{M}\right)$ & $87 \cdot 4 \pm 4 \cdot 8^{\star}$ & $84 \cdot 5 \pm 5 \cdot 9$ & $67 \cdot 3 \pm 5 \cdot 2 \dagger$ & $48 \cdot 2 \pm 9 \cdot 9 \dagger$ \\
\hline Forskolin $\left(10^{-5} \mathrm{M}\right)$ & $84 \cdot 4 \pm 11 \cdot 3^{*}$ & $65 \cdot 2 \pm 9 \cdot 9$ & $61 \cdot 4 \pm 4 \cdot 3 \dagger$ & $46 \cdot 1 \pm 0 \cdot 3 \dagger$ \\
\hline TPA $\left(10^{-6} \mathrm{M}\right)$ & $76 \cdot 1 \pm 5 \cdot 2^{*}$ & $74 \cdot 1 \pm 5 \cdot 5$ & $73 \cdot 6 \pm 13 \cdot 7$ & $73 \cdot 9 \pm 9 \cdot 7$ \\
\hline
\end{tabular}

Symbols $\left({ }^{*}, \dagger\right)$ denote significant difference from basal and agonist-stimulated GLP-1 release respectively $(P<0 \cdot 05)$.

$\left(10^{-11}-10^{-7} \mathrm{M}\right)$ inhibited the forskolin-stimulated GLP1 secretion in a concentration-dependent manner. At the maximally active dose $\left(10^{-7} \mathrm{M}\right)$, galanin decreased the forskolin-induced GLP-1 release by $74 \%(P<0 \cdot 05)$. On the other hand, galanin at the different concentrations tested $\left(10^{-11}-10^{-7} \mathrm{M}\right)$ failed to inhibit GLP-1 secretion induced by TPA.

\section{Effect of pertussis toxin on galanin inhibition of GLP-1 release}

To study the mechanisms underlying the effects of galanin on GLP-1 release, cells were pretreated for $3 \mathrm{~h}$ in the absence or the presence of $200 \mathrm{ng} / \mathrm{ml}$ pertussis toxin before a 1-h incubation with combinations of bombesin or GIP, and galanin (Fig. 5). In the absence of pertussis toxin, galanin $\left(10^{-7} \mathrm{M}\right)$ significantly inhibited GLP-1 release stimulated by $10^{-6} \mathrm{M}$ bombesin $(42.9 \pm 2 \cdot 7$ vs $91 \cdot 6 \pm 3.4 \mathrm{fmol} / 10^{6}$ cells, $\left.P<0 \cdot 05\right)$ or by $10^{-7} \mathrm{M}$ GIP $\left(36 \cdot 5 \pm 1 \cdot 2\right.$ vs $89 \cdot 4 \pm 1 \cdot 6 \mathrm{fmol} / 10^{6}$ cells, $\left.P<0 \cdot 05\right)$. Pertussis toxin treatment did not significantly modify cell viability (78 vs $83 \%$ without toxin), nor basal, bombesinor GIP-stimulated release of GLP-1. However under these conditions, galanin was ineffective in inhibiting the stimulatory action of bombesin $(70 \cdot 2 \pm 2 \cdot 5 \mathrm{vs} 72 \cdot 3 \pm 1 \cdot 4 \mathrm{fmol} /$ $10^{6}$ cells $)$ and of GIP $\left(72 \cdot 2 \pm 4 \cdot 3\right.$ vs $81 \cdot 9 \pm 3 \cdot 2 \mathrm{fmol} / 10^{6}$ cells without galanin).

Involvement of ATP-dependent $\mathrm{K}^{+}$channels in the inhibitory effect of galanin

The selective blocker disopyramide was used to assess the role of ATP-sensitive $\mathrm{K}^{+}$channels in the inhibitory effect of galanin on GLP-1 secretion (Fig. 6). Treatment of cells with $200 \mu \mathrm{M}$ disopyramide preserved the bombesinand GIP-stimulated GLP-1 secretion $(80 \cdot 2 \pm 5 \cdot 1$ and $88 \cdot 1 \pm 4 \cdot 1 \mathrm{fmol} / 10^{6}$ cells respectively, as compared with $37 \cdot 3 \pm 2 \cdot 1 \mathrm{fmol} / 10^{6}$ cells for control, $\left.P<0 \cdot 05\right)$. Under these conditions, galanin only reduced by 46 and $27 \%$ the bombesin- and GIP-induced GLP-1 release respectively.

\section{Discussion}

In the present study, we developed in the adult rat a model of dispersed ileal cells, that were fractionated according to their density by counterflow elutriation, to determine the role of the enteric neuropeptide galanin on GLP1 secretion. Our results indicate that viable mucosal cells, significantly enriched in L-cells, could be prepared from rat ileum for characterization of the cellular mechanisms of GLP-1 secretion. The release of GLP-1 was stimulated by forskolin and the phorbol ester TPA, that increase cAMPdependent protein kinase and protein kinase $\mathrm{C}$ activities respectively. Moreover, exposure of cells to bombesin and GIP induced a significant increase in GLP-1 secretion. These findings are consistent with previous studies performed either in vivo (Roberge \& Brubaker 1993, Roberge et al. 1996) or in the isolated perfused rat ileum and colon models (Plaisancié et al. 1994, Dumoulin et al. 1995, Herrmann-Rinke et al. 1995). They are also in accordance with results obtained in vitro using rat intestinal dispersed cells on the release of GLP-1 (Saiifia et al. 1994, Huang \& Brubaker 1995) or GLI peptides (Brubaker 1991). In addition, the present levels of GLP-1 secretion are similar to those reported using foetal rat intestinal cells, and effects reached statistical significance at similar concentrations of agonists (Brubaker 1988, 1991, Huang \& Brubaker 1995). The present system thus provides a suitable model for studies on the control of GLP-1 secretion.

Our study indicates that galanin inhibits forskolin-, bombesin- and GIP-stimulated GLP-1 secretion from isolated rat ileal cells. Considering the presence of galanin immunoreactive nerves throughout the gastrointestinal tract, with galanin fibres projecting into the mucosa (Rattan 1991), our data suggest that the neuropeptide 


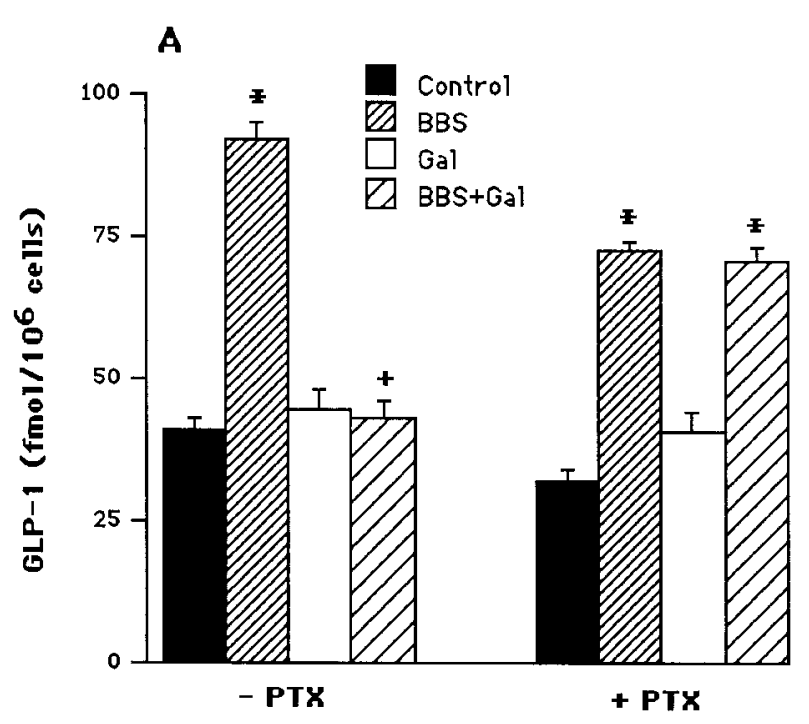

B

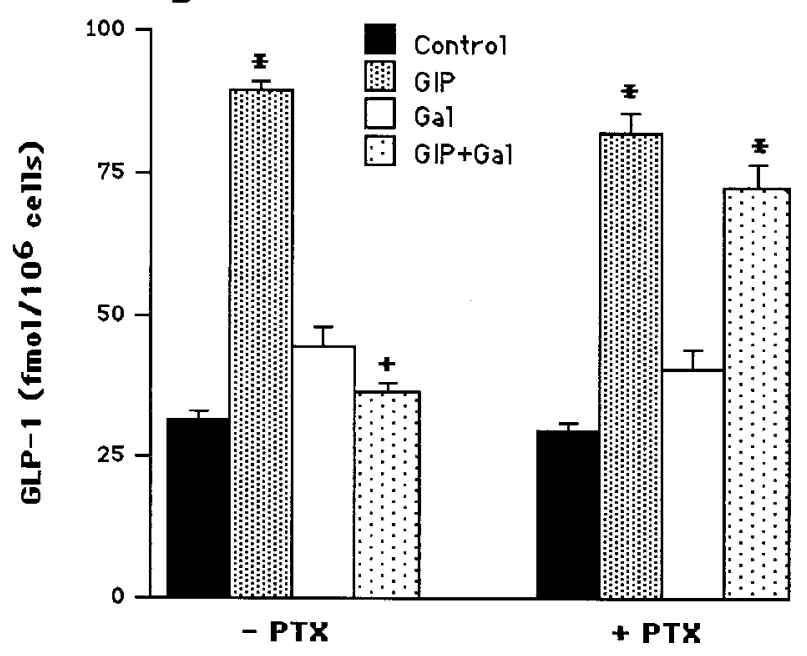

Figure 5 Effect of pertussis toxin on galanin inhibition of bombesin (BBS)- and GIP-stimulated GLP-1 release. Cells were preincubated at $37{ }^{\circ} \mathrm{C}$ for $3 \mathrm{~h}$ without or with $200 \mathrm{ng} / \mathrm{ml}$ pertussis toxin (PTX), then incubated for $1 \mathrm{~h}$ without or with $10^{-6} \mathrm{M}$ BBS (panel A) or $10^{-7} \mathrm{M}$ GIP (panel B) in the absence or presence of $10^{-7} \mathrm{M}$ galanin (Gal). Results are expressed as fmol/ $/ 10^{6}$ cells. Data are the means \pm S.E.M. of three separate experiments each performed in triplicate. ${ }^{*}$ and ${ }^{+}$significantly different from basal and stimulated GLP-1 release respectively $(P<0 \cdot 05)$.

could be a candidate to negatively regulate the postprandial release of GLP-1. This hypothesis is consistent with previous reports that demonstrated an inhibitory effect of galanin on proglucagon-derived peptide secretion (Bauer et al. 1989, Herrmann-Rinke et al. 1996). Interestingly, galanin also exerts inhibitory effects on pancreatic insulin, glucagon and somatostatin secretions (Hramiak et al. 1988,

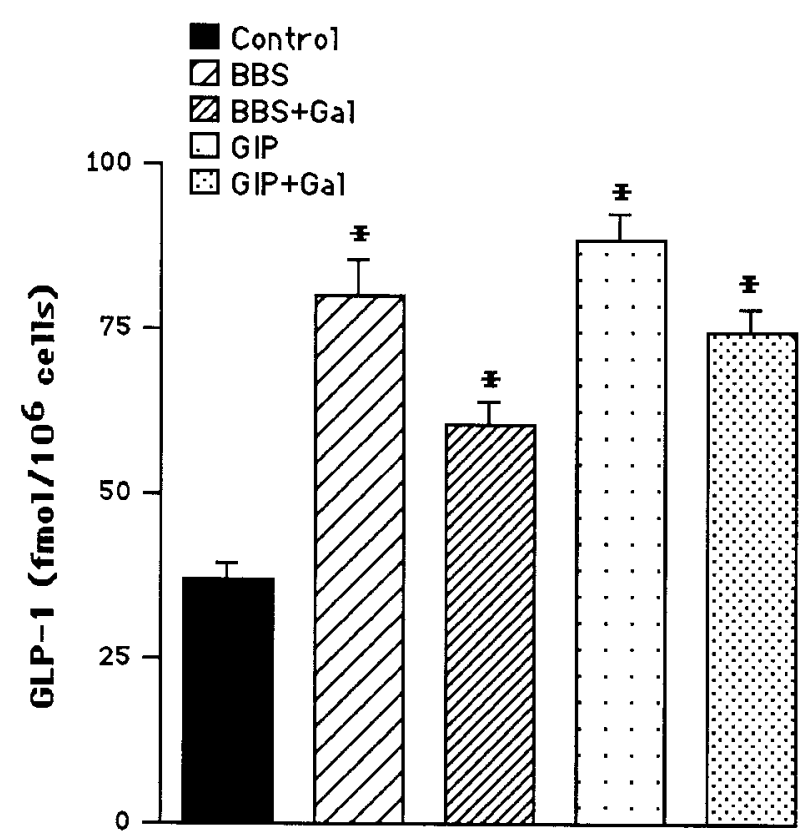

Figure 6 Effect of galanin (Gal) upon $\mathrm{K}^{+}$channel blockade. Cells were preincubated at $37^{\circ} \mathrm{C}$ for 5 min with $200 \mu \mathrm{M}$ disopyramide, then incubated for $1 \mathrm{~h}$ without or with $10^{-6} \mathrm{M}$ bombesin (BBS, hatched bars) or $10^{-7} \mathrm{M}$ GIP (dotted bars) in the absence or presence of $10^{-7} \mathrm{M}$ Gal. Results are expressed as fmol/ $10^{6}$ cells. Data are the means \pm S.E.M. of three separate experiments each performed in triplicate. ${ }^{*}$ Significantly different from basal GLP-1 release $(P<0 \cdot 05)$.

Bauer et al. 1989, Amiranoff et al. 1990). The present study also showed that galanin could counteract the stimulatory effect of adenylate cyclase activation by forskolin, which is consistent with the inhibitory action of the neuropeptide on forskolin- and GIP-stimulated cellular cAMP levels or adenylate cyclase activity in insulin- and somatostatin-secreting cell lines (Amiranoff et al. 1988, 1991). Furthermore, the failure of galanin to inhibit GLP-1 secretion induced by TPA suggests that the inhibitory effects of galanin do not involve protein kinase $\mathrm{C}$, or that galanin is ineffective because TPA has completely desensitized the protein kinase C-dependent pathway.

Because of the heterogeneity of the present preparation of ileal cells, we cannot exclude local/paracrine influences mediating the galanin effects on GLP-1 secretion. Somatostatin is located in nerves and endocrine cells which are in the vicinity of the L-cells. As somatostatin exerts inhibitory effects on endocrine secretions (Sagor et al. 1985, Brubaker 1991), it could be speculated that somatostatin released from D-cells restrained GLP-1 release in our preparation. Somatostatin-like immunoreactivity was indeed detected both in crude and enriched cell preparations. However, galanin did not modify somatostatin release in basal conditions nor upon stimulation with the various agonists, thus excluding an indirect effect of galanin on GLP-1 secretion through somatostatin release. On the other hand, we 
cannot completely rule out the possibility of an indirect effect of galanin via other cell types, e.g. absorptive cells since they express galanin receptors (Homaidan et al. 1994).

A 3-h treatment of cells with pertussis toxin abolished the inhibitory effect of galanin on bombesin- and GIPstimulated GLP-1 secretion, indicating that the galanin receptor is coupled to a pertussis toxin-sensitive G-protein. Similar results were reported on the secretion of insulin from the tumoral cell line RINm5F (Amiranoff et al. 1988, Lang et al. 1994) and from rat pancreatic B-cells (Nilsson et al. 1989). Our data are also in concordance with those obtained in the rat islet cell Rin-m and in the enteroendocrine STC-1 cell lines. In these tumour-like cells, a pertussis toxin treatment reversed the inhibitory effects of galanin on somatostatin and cholecystokinin release respectively (Amiranoff et al. 1990, Chang et al. 1995). The nature of this pertussis toxin-sensitive $G$-protein, i.e. $G_{i}$ and/or $G_{o}$, coupled to the galanin receptor in L-cells is unknown. Recently, the galanin receptor was reported to interact with $G_{\alpha i 2}, G_{\alpha i 3}$ and $G_{\alpha \circ 1}$, leading to inhibition of adenylate cyclase activity and of voltage-gated $\mathrm{Ca}^{2+}$ channels in insulin-secreting cells (Kalkbrenner et al. 1995, McDermott \& Sharp 1995). Further investigations, using native L-cells purified to homogeneity, are needed to identify the $\alpha$-subunit that mediates the inhibitory effect of galanin on GLP-1 secretion.

Previous studies indicated that galanin can act via an opening of $\mathrm{K}^{+}$channels (Ahren et al. 1989, Chang et al. 1995), which would hyperpolarize the membrane and thereby restrict $\mathrm{Ca}^{2+}$ entry via the voltage-dependent $\mathrm{Ca}^{2+}$ channels. A similar involvement of $\mathrm{K}^{+}$channels was here observed using the ATP-dependent $\mathrm{K}^{+}$channel blocker disopyramide, that largely counteracted the inhibitory effect of galanin on the GLP-1 secretion. $\mathrm{K}^{+}$ channels also play a critical regulatory role in the action of somatostatin on insulin-secreting cells (De Weille et al. 1989, Ribalet \& Eddlestone 1995). The question arises whether galanin can affect ATP-dependent $\mathrm{K}^{+}$channel activity directly, through interaction between the transducing $\alpha$-subunit of $G_{i}$ or $G_{o}$ and the ionic channel with consequent increase of activity, or indirectly via diffusible messengers contributing to alterations in the phosphorylation level of the $\mathrm{K}^{+}$channel.

In conclusion, the results of the present study provide evidence of a role for galanin in decreasing GLP-1 release from L-cells as induced by forskolin, GIP and bombesin. Its action involves a pertussis toxin-sensitive G-protein and the activation of ATP-dependent $\mathrm{K}^{+}$channels.

\section{References}

Abello J, Ye F, Bosshard A, Bernard C, Cuber JC \& Chayvialle JA 1994 Stimulation of glucagon-like peptide-1 secretion by muscarinic agonist in a murine intestinal endocrine cell line. Endocrinology 134 2011-2017.
Ahren B, Berggren PO, Bokvist K \& Rorsman P 1989 Does galanin inhibit insulin secretion by opening of the ATP-regulated $\mathrm{K}^{+}$ channel in the B-cell? Peptides 10 453-457.

Amiranoff B, Lorinet AM, Lagny-Pourmir I \& Laburthe M 1988 Mechanism of galanin-inhibited insulin release. European Journal of Biochemistry 177 147-152.

Amiranoff B, Lorinet AM \& Laburthe M 1990 Galanin inhibits somatostatin release by the rat islet cell tumor in culture, Rin-m. European Journal of Pharmacology 191 401-405.

Amiranoff B, Lorinet AM \& Laburthe M 1991 A clonal rat pancreatic $\delta$ cell line (Rin14B) expresses a high number of galanin receptors negatively coupled to a pertussis toxin-sensitive cAMP-production pathway. European Journal of Biochemistry 195 459-463.

Bauer FE, Zintel A, Kenny MJ, Calder D, Ghatei MA \& Bloom SR 1989 Inhibitory effect of galanin on postprandial gastrointestinal motility and gut hormone release in humans. Gastroenterology $\mathbf{9 7}$ 260-264.

Brubaker PL 1988 Control of glucagon-like immunoreactive peptide secretion from fetal rat intestinal cultures. Endocrinology 123 220-226.

Brubaker PL 1991 Regulation of intestinal proglucagon-derived peptide secretion by intestinal regulatory peptides. Endocrinology 128 3175-3182.

Brubaker PL \& Vranic M 1987 Fetal rat intestinal cells in monolayer culture: a new in vitro system to study the glucagon-like immunoreactive peptides. Endocrinology 120 1976-1985.

Chang CHL, Chey WY, Coy DH \& Chang TM 1995 Galanin inhibits cholecystokinin secretion in STC-1 cells. Biochemical and Biophysical Research Communications 216 20-25.

Chayvialle JA, Descos F, Bernard C, Martin A, Barbe C \& Partensky C 1978 Somatostatin in mucosa of stomach and duodenum in gastroduodenal disease. Gastroenterology 75 13-19.

Coons AH, Leduc EJ \& Connolly JM 1955 Studies on antibody production, method for the histochemical demonstration of specific antibody and its application to a study of the hyperimmune rabbit. Journal of Experimental Medicine 102 49-60.

Crawley JN 1995 Biological actions of galanin. Regulatory Peptides 59 $1-16$.

Cuber JC, Philippe C, Abello J, Corring T, Levenez F \& Chayvialle JA 1990 Plasma neurotensin in the conscious pig: release by individual food components and effects on exocrine pancreas secretion. Pancreas 5 306-313.

De Weille JR, Schmid-Antomarchi H, Fosset M \& Lazdunski M 1989 Regulation of ATP-sensitive $\mathrm{K}^{+}$channels in insulinoma cells: activation by somatostatin and protein kinase $\mathrm{C}$ and the role of cAMP. Proceedings of the National Academy of Sciences of the USA $\mathbf{8 6}$ 2971-2975.

Dumoulin V, Dakka T, Plaisancié P, Chayvialle JA \& Cuber JC 1995 Regulation of glucagon-like peptide-1-(7-36) amide, peptide YY, and neurotensin secretion by neurotransmitters and gut hormones in the isolated vascularly perfused rat ileum. Endocrinology $\mathbf{1 3 6}$ $5182-5188$

Gutniak MK, Linde B, Holst JJ \& Efendic S 1994 Subcutaneous injection of the incretin hormone glucagon-like peptide 1 abolishes postprandial glycemia in NIDDM. Diabetes Care 17 1039-1044.

Gutniak MK, Larsson H, Heiber SJ, Juneskans OT, Holst JJ \& Ahren B 1996 Potential therapeutic levels of glucagon-like peptide 1 achieved in humans by a buccal tablet. Diabetes Care 19 843-848.

Herrmann-Rinke C, Vöge A, Hess M \& Göke B 1995 Regulation of glucagon-like peptide-1 secretion from rat ileum by neurotransmitters and peptides. Journal of Endocrinology 147 25-31.

Herrmann-Rinke C, Hörsch D, McGregor GP \& Göke B 1996 Galanin is a potent inhibitor of glucagon-like peptide-1 secretion from rat ileum. Peptides 17 571-576.

Holst JJ 1994 Glucagon-like peptide 1: a newly discovered gastrointestinal hormone. Gastroenterology 107 1848-1855. 
Homaidan FR, Tang SH, Donowitz M \& Sharp GWG 1994 Effects of galanin on short circuit current and electrolyte transport in rabbit ileum. Peptides 15 1431-1436.

Hramiak IM, Dupré J \& McDonald TJ 1988 Effects of galanin on insulin responses to hormonal, neuropeptidal, and pharmacological stimuli in conscious dogs. Endocrinology 122 2486-2491.

Huang THJ \& Brubaker PL 1995 Synthesis and secretion of glucagonlike peptide-1 by fetal rat intestinal cells in culture. Endocrine 3 499-503.

Kalkbrenner F, Degtiar VE, Schenker M, Brendel S, Zobel A, Heschler J, Wittig B \& Schultz G 1995 Subunit composition of $G_{o}$ proteins functionally coupling galanin receptors to voltage-gated calcium channels. The EMBO Journal 14 4728-4737.

Lang J, Boulay F, Parker P, Gierschik P \& Wollheim CB 1994 Regulation of cytosolic calcium and insulin secretion by galanin and ATP receptors: interactions of pertussis toxin-sensitive and -insensitive signalling pathways. Biochemical Journal 303 885-891.

McDermott AM \& Sharp GWG $1995 G_{i 2}$ and $G_{i 3}$ proteins mediate the inhibition of adenylyl cyclase by galanin in the RINm5F cell. Diabetes 44 453-459.

Nilsson T, Arkhammar P, Rorsman P \& Berggren PO 1989 Suppression of insulin release by galanin and somatostatin is mediated by a G-protein. Journal of Biological Chemistry 264 973-980.

Philippe C, Cuber JC, Bosshard A, Rampin O, Laplace JP \& Chayvialle JA 1990 Galanin in porcine vagal sensory nerves: immunohistochemical and immunochemical study. Peptides $\mathbf{1 1}$ 989-993.

Plaisancié P, Bernard C, Chayvialle JA \& Cuber JC 1994 Regulation of glucagon-like peptide-1-(7-36) amide secretion by intestinal neurotransmitters and hormones in the isolated vascularly perfused rat colon. Endocrinology 135 2398-2403.

Rattan S 1991 Role of galanin in the gut. Gastroenterology 100 $1762-1768$.
Reimer RA \& McBurney MI 1996 Dietary fiber modulates intestinal proglucagon messenger ribonucleic acid and postprandial secretion of glucagon-like peptide-1 and insulin in rats. Endocrinology 137 3948-3956.

Ribalet B \& Eddlestone GT 1995 Characterization of the G protein coupling of a somatostatin receptor to the $\mathrm{K}^{+}-\mathrm{ATP}$ channel in insulin-secreting mammalian HIT and RIN cell lines. Journal of Physiology 485 73-86.

Roberge JN \& Brubaker PL 1991 Secretion of proglucagon-derived peptides in response to intestinal luminal nutrients. Endocrinology 128 3169-3174.

Roberge JN \& Brubaker PL 1993 Regulation of intestinal proglucagonderived peptide secretion by glucose-dependent insulinotropic peptide in a novel enteroendocrine loop. Endocrinology 133 233-240.

Roberge JN, Gronau KA \& Brubaker PL 1996 Gastrin-releasing peptide is a novel mediator of proximal nutrient-induced proglucagon-derived peptide secretion from the distal gut. Endocrinology 137 2383-2388.

Sagor GR, Ghatei MA, O'Shaughnessy DJ, Al-Mukhtar MYT, Wright NA \& Bloom SR 1985 Influence of somatostatin and bombesin on plasma enteroglucagon and cell proliferation after intestinal resection in the rat. Gut 26 89-94.

Saifia S, Abello J, Bosshard A \& Chayvialle JA 1994 Peptide YY and truncated glucagon-like peptide 1 secretion from isolated rat intestinal cells. Gastroentérologie Clinique et Biologique 18 447-455.

Thorens B 1995 Glucagon-like peptide-1 and control of insulin secretion. Diabète et Métabolisme 21 311-318.

Received 7 May 1997

Revised manuscript received 30 September 1997 Accepted 30 October 1997 